\title{
Iron Deficiency Anemia in Pregnancy: Intravenous Iron Sucrose versus Oral Iron Sulfate
}

\author{
SHABERAARZOO ${ }^{1}$, SHEREEN YOUSOF ${ }^{2}$, JAHANARA RAHMAN ${ }^{3}$, SAMEENA CHOWDHURY $^{4}$
}

\begin{abstract}
:
Introduction: Injectable iron sucrose and oral ferrous sulfate both are used for the correction of anaemia in second and third trimester of pregnancy. But injectable iron is supposed to be more effective than oral iron, as it needs less time for correction of anaemia and efficacy is more. Oral iron is cost effective but more time consuming.

The objective of the study was to compare the safety of intravenous iron sucrose complex in the treatment of iron deficiency anemia in third trimester of pregnancy. To compare the efficacy of intravenous iron with oral iron.

Method: A randomised controlled trial was conducted in which pregnant women with iron deficiency were sequentially selected from the pregnant women attended antenatal clinic of OPD of Institute of Child and Maternal Health (ICMH) and assigned either to injectable or to oral ferrous sulfate by random number table. Each study patient was given the total calculated amount of injectable iron sucrose $\{\mathrm{Hb}$ deficit $(\mathrm{gm} / \mathrm{l}) \times$ body weight $(\mathrm{kg}) \times 0.24+$ storage iron $\mathrm{mg}\}$ in divided dose $200 \mathrm{mg}$ in $200 \mathrm{ml}$ normal saline intravenously over 1 hour every alternate day. Each patient of the control group was given ferrous sulfate $200 \mathrm{mg}$ orally three times a day for 4 weeks. Pregnant women follow up at 4 weeks and 8 weeks after get treatment by oral and injectable iron. During follow up monitored for adverse effects, clinical and laboratory response and haemoglobin percentage were observed.

Result: There were 75 patients in injectable group and 75 patients in oral group. Injectable group achieved a significantly higher $\mathrm{Hb}$ level (11.49 \pm 0.39$)$ than oral group $\mathrm{Hb}$ level (10.39 $\pm 0.75)$ after 8 weeks of treatment. Injectable group showed no major side effects, only two patient had complains. One patient complain of epigastic pain and one patient complain of tachycardia while in oral group complain of nausea and vomiting, epigastic pain, constipation, allergic reaction was found in $42.0 \%, 39.3 \%, 35.7 \%$ and $3.6 \%$ respectively.
\end{abstract}

Conclusion: Iron sucrose complex appears to be a safe and effective in the treatment of iron deficiency anemia.

Key word: Iron deficiency anemia in pregnancy, Injectable iron, oral iron.

\section{Introduction:}

Anaemia was estimated to effect nearly two third of the pregnant women in developing countries ${ }^{1}$. Iron deficiency anaemia is the most common nutritional deficiency anaemia worldwide. It is responsible for $95 \%$ of the anaemia during pregnancy ${ }^{1-3}$. The prevalence of iron deficiency anaemia in developing countries is approximately $52 \%{ }^{4}$. In pregnancy, the total volume of plasma is dramatically increased $(50 \%)$ along with increase in red cell mass (18-25\%) depending on iron status, and the haemoglobin is consequently reduced to a varying extent, occasionally as low as $80 \%$ making anaemia the most common hematological abnormality diagnosis

1. Assistant Professor, Gynae and obs department, Eastern medical college and hospital, Comilla

2. Medical Officer, Gynae and obs department, BSMMU, Dhaka

3. Professor,Gynae and obs department, National medical college and hospital ,Dhaka

4. Ex Professor and head of the department, Gynae and Obs Department, Institute of Child and Mother Health (ICMH), Dhaka.

Address of Correspondence: Dr Shabera Arzoo, Assistant Professor, Gynae and obs Department, Eastern medical college and hospital, Comilla, Mobile:01711385778, Email:arzooshabera@gmail.com. 
during pregnancy ${ }^{5}$. Most women of developing countries begin their pregnancy with partially depleted iron reserve.

Tissue enzyme dependent on iron can affect cell function in nerves and muscles. As a result the fetus may suffer from poor fetal growth, preterm birth and low birth weight. Anaemia is implicated as the direct contributor of post partum hemorrhage which is leading cause of maternal mortality.

To correct anaemia iron can be supplemented by mouth, intramuscular or intravenous injection. Blood transfusion is used when indicated. Oral iron supplementation can be given with iron salts like ferrous sulphate, ferrous fumerate which has prominent gastrointestinal disturbance ${ }^{6}$. Oral iron is frequently restricted by limited absorption, low tolerability, non compliance and side effects. On the other hand parenteral iron supplementation has quite rightly grown in popularity over the past few decades. Parenteral administration of iron can be given by two routes, intramuscular and intravenous.

Intravenous iron has been shown to be safer with fewer side effects and less adverse reactions. Iron sucrose that release iron to the endogenous iron bindings protein with a half life of about 6 hours are not only effective but carry a minimum risk of allergic accident and overload ${ }^{7}$. Iron sucrose complex is recommended to use intravenously for the correction of iron deficiency anaemia ${ }^{8}$.

\section{Materials and Method:}

A randomized controlled trial was conducted at ICMH during the period of July, 2008 to December 2008. In the study total 150 cases of primi or multigravida singleton pregnant women with iron deficiency anemia $(\mathrm{Hb}$ level below $10 \mathrm{gm} / \mathrm{dl}$ ) at 24 to 32 weeks of gestational were included in the study. Pregnant anemic woman's whose $\mathrm{Hb} \%$ below $6 \mathrm{gm} / \mathrm{dl}$ and pregnancy less then 24 weeks and above 32 weeks were excluded. A pregnant anemic woman's whose anemia not linked to iron deficiency, asthma, cirrhosis, viral hepatitis, multiple pregnancy, risk of premature birth, suspected acute infection, perenteral iron treatment before and intolerance to iron derivatives were also excluded.

Details history was obtained and clinical exam was done. Some related investigations like iron profile, serum feritin level and Peripheral Blood Fitus and red cell indices (PBF) were done. Proper counseling was done and informed written consent was obtained from each patient. Selected patients were randomly divided into two groups for correction of anaemia using oral and injectable iron .

For randomization a sequentially numbers selected envelops were used cases and controlled were selected by caption generated random number tables. Each study patient ( $n-75)$ was given the total calculated amount of injectable iron sucrose $\{\mathrm{Hb}$ deficit $(\mathrm{gm} / \mathrm{l})$ body $\times$ weight $(\mathrm{kg}) \times 0.24+$ storage iron $\mathrm{mg}\}$ in divided dose $200 \mathrm{mg}$ in $200 \mathrm{ml}$ normal saline intravenously over 1 hour every alternate day. Each patient of the control group ( $\mathrm{n}-75)$ was given ferrous sulfate $200 \mathrm{mg}$ orally three times a day . Post treatment. Follow up at 4 week and 8 week after oral and injectable iron therapy to see $\mathrm{Hb} \%$, side effects or any complications .

SPSS (version 14) statistical software was used for data analysis.The result expressed as the mean (ISP), percentage and range. Comparison was done using $t$ test $\&$ chi square test; $p$ value $<0.05$ was considered significant.

\section{Result:}

No participants were lost to follow up and there were no dropouts. Count of back cover of iron tablets collected from women in the oral iron group showed that all women took oral iron medication. All selected women received the calculated total iron dose.

Initial demographic and clinical characteristics were similar in the two groups. The mean age of women on inclusion in intravenous group was $25.63 \pm 5.14$ years with mean gestational age of $27.57 \pm 1.84$ weeks, mean hemoglobin of $7.96 \pm 0.80$ . In the oral group, mean age was $26.81 \pm 4.43$ years with gestational age of $27.96 \pm 1.50$ weeks, mean hemoglobin $7.97 \pm 0.77$.

An increase in hemoglobin was observed from baseline to 4 weeks and 8weeks in each group, but the increase in hemoglobin in intravenous iron sucrose group was more than oral ferrous sulfate group at each point of measurement $(P<0.001)$ as shown in (Table-I) .

There were no serious adverse drug reactions recorded. There were no episodes of anaphylaxis or hypotensive shock. There were no patient withdrawals and no drug discontinuation caused by drug related adverse events in the intravenous group. 
Adverse events in the intravenous group were Abdominal pain (one), Tachycardia (one). Only two patients had adverse reactions (Table-I)

Table-II shows comparison of pretreatment and 4 weeks and 9 weeks posttreatment haemoglobin level between oral group and injectable group showed that pretreatment mean+ $\mathrm{SD} \mathrm{Hb}(\mathrm{g} / \mathrm{dl})$ level was $7.97+0.77$ and $7.96+0.80(P>0.50)$ after 4 weeks treatment was $9.24+0.57$ and $10.77+0.46(P<0.001)$ and after 9 weeks treatment was $10.39+0.57$ and 11.49+0.39 $(P<0.001)$ (Table-III)

The mean differences of haemoglobin level in both oral group and injectable group were highly significant $(P<0.001)$ when compared between prettreatment and after 4 weeks and 9 weeks treatment, between and after 4 weeks treatment and after 9 weeks treatment.

In oral group and injectable group patients, improvement of haemoglobin level after 4 weeks treatment was $16.36 \%$ and $36.61 \%$ and after 9 weeks treatment was $31.21 \%$ and $45.91 \%$ respectively, from pretreatment level. Improvement after 9 weeks treatment was $12.85 \%$ and $7.83 \%$ respectively from 4 weeks treatment level.

In the oral group gastrointestinal symptoms were experienced by 27 women. Twelve women had nausea and vomiting,eleven women had epigastric discomfort, and one women had allergic reaction which was managed by symptomatic treatment. No women discontinued the drug because of gastrointestinal symptoms. (Table-2).

Table-I

Pretreatment and post treatment haemoglobin status

\begin{tabular}{|c|c|c|c|}
\hline $\mathrm{Hb}(\mathrm{g} / \mathrm{dl})$ & $\begin{array}{c}\text { Group A } \\
(n=75) \\
\text { Oral }\end{array}$ & $\begin{array}{c}\text { Group B } \\
\left(\begin{array}{c}n=75) \\
\text { Inj }\end{array}\right. \\
\end{array}$ & $\begin{array}{c}\text { P Value } \\
\text { t value } \\
\text { df }\end{array}$ \\
\hline Pretreatment & $7.97+0.77$ & $7.96+0.80$ & $>0.50$ \\
\hline $\begin{array}{l}\text { Mean+SD } \\
\text { Range }\end{array}$ & $6.00-9.60$ & $6.00-9.60$ & $\begin{array}{c}0.073 \\
148\end{array}$ \\
\hline Posttreatment & $9.24+0.79$ & $10.77+0.46$ & $<0.001$ \\
\hline $\begin{array}{l}\text { After } 4 \text { weeks } \\
\text { Mean+SD } \\
\text { Range }\end{array}$ & $7.50-11.00$ & $9.50-12.00$ & $\begin{array}{c}-14.438 \\
148\end{array}$ \\
\hline $\begin{array}{l}\text { Improvement (\%) } \\
\text { from pretreatment }\end{array}$ & 16.36 & 36.61 & \\
\hline After 9 weeks & $10.39+0.57$ & $11.49+0.39$ & $<0.001$ \\
\hline $\begin{array}{l}\text { Mean+SD } \\
\text { Range }\end{array}$ & $8.90-11.50$ & $10.20-12.00$ & $\begin{array}{c}-13.816 \\
148\end{array}$ \\
\hline $\begin{array}{l}\text { Improvement (\%) } \\
\text { from pretreatment }\end{array}$ & 31.21 & 45.91 & \\
\hline $\begin{array}{l}\text { Improvement (\%) } \\
\text { from } 4 \text { weeks }\end{array}$ & 12.85 & 6.83 & \\
\hline ANOVA test & $P$ value & $P$ value & \\
\hline $\begin{array}{l}\text { Pretreatment vs } \\
\text { 4-week treatment }\end{array}$ & $<0.001^{* * *}$ & $<0.001^{* * *}$ & \\
\hline $\begin{array}{l}\text { Pretreatment vs } \\
\text { 9-week treatment }\end{array}$ & $<0.001^{* * *}$ & $<0.001^{* * *}$ & \\
\hline $\begin{array}{l}\text { 4-week treatment vs } \\
\text { 9-week treatment }\end{array}$ & $<0.001^{* * *}$ & $<0.001^{* * *}$ & \\
\hline
\end{tabular}

Unparied students $Y$ test/ANOVA test ns $=$ Not significant, ${ }^{* * *}=$ Significant 
Table-II

Types of side effects after injectable and oral iron therapy

\begin{tabular}{lcc}
\hline Type of side effects & Oral group $(n=75)$ & InjectableGroup $(n=75)$ \\
& No $(\%)$ & No $(\%)$ \\
\hline Allergic reaction & $1(1.3)$ & 0 \\
Nausea/vomiting & $12(16.0)$ & 0 \\
Abdominal pain & $10(13.31)$ & $1(1.3)$ \\
Epigastic pain/heart burn & $11(14.68)$ & 0 \\
Tachycardia & 0 & $1(1.3)$ \\
\hline
\end{tabular}

Table-III

Comparison of side effects

\begin{tabular}{lccc}
\hline Side effects & Oral Group $(n=75)$ & Injectable Group $(n=75)$ & Level of significant \\
\hline Present & $28(37.3)$ & $2(2.7)$ & P value $<0.001^{* * *}$ \\
Absent & $47(62.0)$ & $73(97.3)$ & X2 value 28.167 \\
\hline
\end{tabular}

Chi-square test

${ }^{* * *}=$ significant

\section{Discussion:}

The study confirmed that parenterally administered iron sucrose elevated hemoglobin better than oral ferrous sulfate.

Al Momen et al ${ }^{9}$ in their study compared 52 women treated with intravenous iron sucrose and 59 women treated with $300 \mathrm{mg}$ oral iron sulfate. Intravenous iron sucrose complex group achieved significantly higher hemoglobin levels $128.5 \pm 6.6$ versus $111.4 \pm 12.4 \mathrm{~g} /$ I in the oral iron group $(P<0.001)$ in a shorter period $6.9 \pm 1.8$ versus $14.9 \pm 3.1$ weeks in control group $(P$ d" 0.001). Iron sucrose complex group showed no major side effects while 4 (6\%) of the control group could not tolerate ferrous sulfate, 18 (30\%) complained of disturbing gastrointestinal symptoms, and $18(30 \%)$ had poor compliance. The authors concluded that iron sucrose was a safe and effective alternative in the treatment of iron deficiency anemia during pregnancy ${ }^{10}$. This study is comparable to our study in that hemoglobin concentration was higher in the intravenous group in a shorter period of time.

In the study done by Bayoumeu et al. ${ }^{11}$, involving 50 women intravenous iron sucrose was compared with oral ferrous sulfate. In the intravenous group an increase in hemoglobin was observed rising from $9.6 \pm 0.79$ to $11.11 \pm 1.3 \mathrm{~g} / \mathrm{dl}$ on day 30 and from $9.7 \pm 0.5$ to $11 \pm 1.25 \mathrm{~g} / \mathrm{dl}$ on day 30 in the oral group which was not significant. This study slightly different from our study because sample size was small and iron sucrose was given over 21 days.

In a study by Al RA et al ${ }^{12}$. compared intravenous iron sucrose with oral iron polymaltose complex (300 mg elemental iron per day). The change in hemoglobin from baseline was significantly higher in the intravenous group than the oral group at each measurement; the changes with respect to subsequent hemoglobin were significantly higher on day 14th $(P=0.004)$ and 28th $(P=0.031)$. This study is comparable to our study because there was a significant rises in hemoglobin and ferritin levels in intravenous group compared to oral group.

\section{Conclusion:}

Iron sucrose is an effective alternative to oral ferrous sulfate in the treatment of iron deficiency anaemia of pregnancy. Intravenous iron sucrose produce a more rapid increase in haemoglobin concentration than oral iron .Intravenous iron therapy is a safe alternative for the treatment of anaemia, being able to reduce the need of blood transfusion and its concomitant side effects. During pregnancy it help to rebuild iron stores, helping the symptoms oe anaemia to subside at a faster rate and reduce the risk of developing anaemia in subsequent pregnancies. Tolarance seems to be excellent in injectable iron then oral iron. Major sdvantage are safety, efficacy, compliance and can administrate in an out patient setting. 


\section{Referance:}

1. Breymann C. Iron deficiency and anemia in pregnancy : Modern aspects of diagnosis and therapy. Blood cell 2002, 29; $506-16$.

2. Breymann C. Anemia working group current aspects of diagnosis and therapy of iron deficiency anemia; Schweiz Rundsch Med Prax 2001; 90:1283 - 91 .

3. Yaqoob N, Abbasi SM. Nutritional Iron deficiency in our Population J. coll physicians Surg Pak 2002.4. Worldwide prevalence of anaemia 1993-2005. WHO Global Database on Anaemia, Switzerland, 2008.

5. Letsky E.A. - Anemia. In: James DK, Steer PJ,Weiner CP Gonik B, editors. High Risk Pregnancy -Management Options, 2nd ed. London: WB Saunders;729-747, 1999.

6. Devsthali SD, Gorteuk VR, Brittenham GM, et al. Bioavailability of Carbonyl iron ; A randomised double blinded study. Eur J Hematol 1991; 46(5):272 -78.s

7. Perewusnyk G., Huch R., Huch A., Breymann C. Parenteral iron therapy in obstetrics: 8 years experiencewith iron-sucrose complex. Br J Nutr 88: 3-10, 2002.

8. Perewusny KG, Huck R, Huck A. Breymann C. Parenteral iron - Sucrose complex. Br J Nutr 2002; 88: 3-10.

9. Beshara $\mathrm{S}$, Lundqvist $\mathrm{H}$, Sundin $\mathrm{J}$, et al. Pharmacokinetics and red cell utilization of iron(III) hydroxide-sucrose complex in anaemic patients: a study using positron emission tomography. Br J Haematol. 1999;104:296302. doi: 10.1046/j.1365-2141.1999.01179.x.

10. al-Momen AK, al-Meshari A, al-Nuaim L, et al. Intravenous iron sucrose complex in the treatment of iron deficiency anemia during pregnancy. Eur J Obstet Gynecol Reprod Biol. 1996;69:121-124.

11. Bayoumeu F, Subiran-Buisset C, Baka NE, et al. Iron therapy in iron deficiency anemia in pregnancy: intravenous route versus oral route. Am J Obstet Gynecol. 2002;186:518-522.

12. AL RA, Unlubilgin $E$, Kandemir $O$, et al. Intravenous versus oral iron for treatment of anemia in pregnancy: a randomized trial. Obstet Gynecol. 2005;106:1335-1340. 